Pak. j. sci. ind. res. Ser. A: phys. sci. 2018 61A(2) 115-120

\title{
Review \\ Economic Analysis of the Production of Electricity Generation and Fuel Oil from Different Renewable Resources in Pakistan
}

\author{
Atif Khan*, Hassan Javed Naqvi, Shabana Afzal, Zohaib Ashraf and Sana Zahid \\ Department of Chemical Engineering, University of Engineering and Technology, Lahore-54890, Pakistan
}

(received August 24, 2017; revised February 20, 2018; accepted March 26, 2018)

\begin{abstract}
Pakistan is in the list of those countries which are facing huge energy crisis chronologically. Capacity of electricity generation from main resources is declining due to improper maintenance. Conventional resources are also depleting with the passage of time causing increase in cost of power generation. Keeping in view of these issues, other renewable resources of power generation should be taken into consideration. Pakistan is an agricultural land therefore, it is rich in some of the renewable resources of energy like biomass e.g., rice husk, wheat straw and domestic plastic waste that can be utilised to produce power by application of certain available technologies. Similarly, use of plastic waste to produce diesel is increasing day by day and its disposal is going to be a great challenge in future. This research is basically an economic review focusing on the cheap cost of electricity and diesel if above mentioned renewable resources are utilised.
\end{abstract}

Keywords. economic analysis, gasification, pyrolysis, biomass, electricity, diesel

\section{Introduction}

Pakistan is in the list of those countries of the world who are facing huge energy crisis. Energy demand and supply gap is increasing in chronological way every year (Amjid et al., 2011). Due to the war against terrorism in northern areas of Pakistan, risk of depletion of the energy resources increased tremendously and overall economy of the country is affected very much (Qureshi et al., 2003; Noman, 1988). Among various problems in Pakistan, electricity shortfall is the most challenging and major problem which is directly influencing and declining the business opportunities at larger and smaller scales (Jamil, 2013; Siddiqui et al., 2008). Local and foreign investors are showing lack of interest for doing investment because of energy crisis. At domestic level electricity short fall is increasing and especially in summer season it increases tremendously (Newsham and Bowker, 2010; Hammer et al., 1982). Besides some political reasons, major reason is the decrease in conventional resources of energy. Major resource of electricity in Pakistan is through hydal resources. There are total two major dams "Tarbela Dam' and "Mangla Dam" which are working at their full capacity for contribution in electricity generation (Tariq and van de Giesen, 2012; Myers, 1997; Frost,

*Author for correspondence; E-mail: arif.khan@uet.edu.pk
1973). Some dams are working at very small capacity and their contribution in electricity generation is not sufficient enough. Due to increase in population, improper maintenance and declining level of water each year in these dams their capacity is decreasing which ultimately leads to great electricity shortfall (Hayat, 2007; Qureshi, 2005). If no attention would be given to these dams, then a great threat of complete depletion of electricity will happen in upcoming years (Kessides, 2013; Kugelman, 2013).

In the light of the above discussion, it is very important to generate power through different resources available in Pakistan. For this purpose, initiative has been taken towards the electricity generation through renewable resources (Sheikh, 2010; Sahir and Qureshi, 2008). Pakistan is considered an agricultural country because $70 \%$ of population depends upon agricultural outcome. Therefore, there are variety of renewable resources available in Pakistan in abundant quantity (Amer and Daim, 2011; Mirza et al., 2010). Among these renewable resources biomass are of great importance. These biomasses include rice husk, wheat straw and corn cob etc. (Bhutto et al., 2011; Mirza et al., 2008; Bhattacharya and Salam, 2002). Similarly, other renewable resources include waste plastic, waste wood and waste paper which can be used for fuel production (Batool and 
Chuadhry, 2009; Shekdar, 2009; Batool et al., 2008; Khan and Abu-Ghararah, 1991). Huge quantity of food waste and cloth waste is generating per day which can also be used for this purpose. Hence, besides power generation other advantage is effective waste management which ultimately helps in pollution reduction (Sthiannopkao and Wong, 2013; Polprasert, 2007; Dinda, 2004). Although research work has been done for the development of the technology for power generation using these renewable resources but all these technologies are applied at very small scale. Further and extensive research is required in this area for the application on these technologies on massive scale (Sahir and Qureshi, 2008; Berndes, 2002). The major purpose of this review is basically to enlighten the importance of these technologies on the enhancement of overall economy of Pakistan and also its cheaper cost as compared to conventional resources of electricity which reduces a huge burden of consumers for their electricity charges. On massive scale this technology is capable enough to contribute in overall electricity load of Pakistan (Khan, 2015; Khan et al., 2015).

Overview of different renewable energy technologies. Gasification technology. In gasification, agricultural waste (biomass) is converted into different gases. These gases are collectively known as producer gas and its composition is given in Table 1 (Fermoso et al., 2009). There are two major categories of gasification technology which are "Producer gas production through direct firing" and "production of gases through gasification systems". In direct firing producer gas is generated by direct application of heat in fluidized bed boilers and stocker boilers while in gasification system fixed bed gasifiers and fluidized bed gasifiers are used. Normally direct firing systems are preferred because of its low capital and installation cost. Biomass which serves as a fuel in direct firing systems are burnt for steam production which is used to run steam turbine for electricity production. Basically, biomass is heated in such an environment where it is converted into combustible gas with high energy content in the form

Table 1. Composition of gasification product

\begin{tabular}{ll}
\hline \hline Nitrogen & $50-60 \%$ \\
\hline Carbon dioxide & $8-11 \%$ \\
Carbon monoxide & $17-19 \%$ \\
Methane & $14-18 \%$ \\
Hydrogen & $13-17 \%$ \\
Gross calorific value & $900-1100 \mathrm{kcal} / \mathrm{m}^{3}$ \\
\hline \hline
\end{tabular}

of heat, which is further used for different purposes. According to survey reports almost 1232011 tonnes per year of biomass is produced in Pakistan (Mirza et al., 2008). Capacity of electricity generation through these systems are between 30-50MW (Laurikka, 2006; Dasappa et al., 2004; Morris and Waldheim, 1998).

Production of biogas through anaerobic digestion process. Production of gases from animal dunk/manure provides a great advantage to the rural population in Pakistan. Now a days Pakistan is suffering from a natural gas shortage because of declining gas reserves and chronological increase in population. Biogas usage is not only economical but also helps in reduction of all types of animal waste making clean and green environment. Biogas production requires a lot of field work which includes collection and transportation of animal waste on continuous basis. Biogas is basically a good substitute to a natural gas mostly used at domestic level for cooking and lighting. It is very attractive source for local farmers for additional income. Animal manure is mixed with water in a specific proportions and some settling time is given. Bacteria which are present inside the manure oxidize the organic matter inside manure which results in the production of biogas. Bacteria oxidize the organic matter through digesting them in the absence of air, therefore it is also known as anaerobic digestion. The biogas plant is not only used for energy generation but also its byproduct which is known as substrate is a very good natural fertilizer (Amjid et al., 2011; Weiland, 2010 Chen, et al., 2008; Gunaseelan, 1997; Nazir, 1991; ). Literature reveals that biogas has the potential of producing $23,654 \mathrm{GWH}$ of electricity from 368434650 tonnes per year of manure (Amjid et al., 2011). The composition of biogas produced through digestion process is given in Table 2 (Zhang et al., 2007).

Energy generation through pyrolysis. Pyrolysis is the thermal decomposition of carbonaceous material in the absence of oxygen to produce char, gas, and a liquid product rich in oxygenated hydrocarbons. In general, pyrolysis is performed using a range of temperatures and residence times to optimize the desired product. The biomass is heated to approximately $500{ }^{\circ} \mathrm{C}$ in less than $1 \mathrm{sec}$ and then rapidly cooled to stop the reaction. The liquid product, known as bio-oil, is obtained in yields up to $75 \%$ by weight on a dry feed basis. It can also be upgraded to lower the oxygen content and transported using the same trillion-dollar infrastructure used by the oil industry. In addition to being transported and stored at a lower cost than solid biomass, bio-oil 
and upgraded oil can be used in applications ranging from value-added chemicals to transportation fuels. Although pyrolysis can produce considerable amount of bio-oils, their direct applications as fuels are limited by the problems of high viscosity, high oxygen content and corrosion, as well as their thermal instability. Therefore, bio-oils should be upgraded using proper methods before they can be used in diesel or gasoline engines (Yang, et al., 2007; Mohan et al., 2006; Miao and Wu, 2004; Adjaye and Bakhshi, 1995; Shafizadeh, 1982).

Feasibility survey and cost comparison. Cost comparison has been discussed on rice husk, waste wood and domestic plastic waste. Rice husk, and waste wood is discussed for the production of bio-diesel through gasification technique while the cost for biodiesel production through plastic waste is discussed through pyrolysis process(Lynd, 1996). One unit of electricity requires 0.08 liters of diesel, $1.1 \mathrm{~kg}$ of wood and $1.4 \mathrm{~kg}$ of rice husk. Currency value used here is Pakistani rupees (PKR) (Mirza et al., 2008).

From the comparison in Table 3 it is quite clear that biomass usage for electricity generation is a very good substitute to conventional resources. It is not only less in price but also abundantly available. Here cost comparison is showed both in combination of biomass with diesel for the production of electricity and independent usage of biomass. Independent usage of biomass or in combination with conventional fuel depends upon the circumstances. Due to geographical

Table 2. Composition of biogas from different types of manure

\begin{tabular}{|c|c|c|c|c|c|c|c|}
\hline $\begin{array}{l}\text { Type of } \\
\text { manure }\end{array}$ & $\begin{array}{l}\text { Organic } \\
\text { composition }\end{array}$ & $\begin{array}{l}\mathrm{C} / \mathrm{N} \\
\text { ratio }\end{array}$ & $\begin{array}{l}\text { Dry } \\
\text { matter \% }\end{array}$ & $\begin{array}{l}\text { Veterinary } \\
\text { safety ( } \% \text { of } \\
\text { dry matter) }\end{array}$ & $\begin{array}{l}\text { Biogas yield } \\
\mathrm{m}^{3} / \mathrm{kg}\end{array}$ & $\begin{array}{l}\text { Physical } \\
\text { impurities }\end{array}$ & $\begin{array}{l}\text { Unwanted } \\
\text { matters }\end{array}$ \\
\hline $\begin{array}{l}\text { Pig } \\
\text { slurry }\end{array}$ & $\begin{array}{l}\text { Proteins, } \\
\text { Carbohydrates } \\
\text { Lipids }\end{array}$ & $3-10$ & $3-8$ & $70-80$ & $0.25-0.50$ & $\begin{array}{l}\text { Wood shavings, } \\
\text { bristles, water, } \\
\text { sand, straw }\end{array}$ & $\begin{array}{l}\text { Antibiotics, } \\
\text { Disinfectants }\end{array}$ \\
\hline $\begin{array}{l}\text { Cattle } \\
\text { slurry }\end{array}$ & $\begin{array}{l}\text { Same as } \\
\text { above }\end{array}$ & $6-20$ & $5-12$ & 80 & $0.20-0.30$ & $\begin{array}{l}\text { Bristles, } \\
\text { soil, water, } \\
\text { straw, wood }\end{array}$ & $\begin{array}{l}\text { Antibiotics, } \\
\text { Disinfectants, } \\
\mathrm{NH}_{4}^{+}\end{array}$ \\
\hline $\begin{array}{l}\text { Poultry } \\
\text { slurry }\end{array}$ & $\begin{array}{l}\text { Same as } \\
\text { above }\end{array}$ & $3-10$ & $10-30$ & 80 & $0.35-0.60$ & $\begin{array}{l}\text { Grit, sand, } \\
\text { feathers }\end{array}$ & $\begin{array}{l}\text { Same as } \\
\text { above }\end{array}$ \\
\hline
\end{tabular}

Table 3. Cost comparison for electricity generation when diesel and biomass used together

\begin{tabular}{|c|c|c|c|}
\hline Description & $\begin{array}{l}\text { Amount of fuel } \\
\text { required per unit } \\
\text { of electricity }\end{array}$ & Price of fuel in PKR & $\begin{array}{l}\text { Total cost per unit of } \\
\text { electricity in PKR }\end{array}$ \\
\hline Fuel & ------------------'--------- & -------------------'-------- & ---------------------------- \\
\hline Diesel & 0.08 liter & 72.52/liters & 5.8016 \\
\hline Wood & $1.1 \mathrm{~kg}$ & $6 / \mathrm{kg}$ & 6.6 \\
\hline Rice husk & $1.4 \mathrm{~kg}$ & $3.5 / \mathrm{kg}$ & 4.9 \\
\hline $\begin{array}{l}\text { Total fuel cost } \\
\text { when diesel and } \\
\text { wood used together }\end{array}$ & ------------------------------- & ------------------------------- & 12.4016 \\
\hline $\begin{array}{l}\text { Total fuel cost when } \\
\text { diesel and rice husk } \\
\text { used together }\end{array}$ & --------------------------- & ------------------------ & 10.7016 \\
\hline $\begin{array}{l}\text { Cost of unit of electricity } \\
\text { when only diesel used } \\
\text { ( } 1 \text { liter of diesel is equal to } \\
3.5 \text { units of electricity) }\end{array}$ & --------------------------- & --------------------------- & 20.72 \\
\hline
\end{tabular}


Table 4. Cost estimation for production of fuel oil from plastic waste

\begin{tabular}{lllllll}
\hline \hline Input & $\begin{array}{l}\text { Quantity } \\
\text { (Input kg) }\end{array}$ & Rate per kg & $\begin{array}{l}\text { Amount } \\
\text { Pakistan rupees }\end{array}$ & Output & $\begin{array}{l}\text { Quantity } \\
\text { produced (liters) }\end{array}$ & $\begin{array}{l}\text { Rate in Pakistan } \\
\text { rupees/L }\end{array}$ \\
\hline Plastic & 1.00 & 12.00 & 12.00 & Petrol & 0.300 & $19.50 / 0.3=65$ \\
Labor & ------ & ------ & 5.00 & Fuel oil & 0.600 & $19.50 / 0.6=32.5$ \\
Service & ------ & ----- & Lube oil & 0.100 & $19.50 / 0.1=195$ \\
$\begin{array}{l}\text { Charges } \\
\text { Total }\end{array}$ & 1.00 & ------- & 190 & --50 & 1.00 & ---- \\
\hline \hline
\end{tabular}

conditions and some certain constraints in some areas of Pakistan, biomass is not abundantly available or its availability is limited due to some transportation issues. In this case biomass is used in combination with diesel for power generation (Khan, 2015). In Table 4 (Khan et al., 2015) cost analysis is carried out for the production of bio-diesel from the domestic plastic waste.

Plastic waste is used because of its readily availability. Further its disposal problem is going to be a bigger challenge so its utilization for useful purpose is very much important. Hence, it is converted into biodiesel through pyrolysis process.

Basis $=1000$ Tonnes/day plastic

Fuel oil produced per day $=(1000) \times(1000) \times 0.6$ $=* 600000 \mathrm{~L} /$ day

$*=\mathrm{kg}$ of plastic is approximately taken equal to liters of plastic for ease of calculation.

\section{Conclusion}

From above discussion it is quite obvious that power generation from biomass resources are very cheaper and affordable in price. Energy demand and supply gap can be reduced very easily if initiatives are taken at government level for development of these projects on domestic and industrial scale. These projects are so far applied on small scale so further initiative is required for application of these projects on large scale.

\section{Acknowledgement}

All researchers are very thankful to University of Engineering and Technology Lahore, Pakistan for their complete financial support for this research.

\section{References}

Adjaye, J. D., Bakhshi, N. 1995. Production of hydrocarbons by catalytic upgrading of a fast pyrolysis bio-oil. Part I: Conversion over various catalysts. Fuel Processing Technology, 45: 161183.

Amer, M., Daim, T. U. 2011. Selection of renewable energy technologies for a developing county: a case of Pakistan. Energy for Sustainable Development, 15: 420-435.

Amjid, S. S., Bilal, M. Q., Nazir, M. S., Hussain, A. 2011. Biogas, renewable energy resource for Pakistan. Renewable and Sustainable Energy Reviews, 15: 2833-2837.

Batool, S. A., Chaudhry, N., Majeed, K. 2008. Economic potential of recycling business in Lahore, Pakistan. Waste Management, 28: 294-298.

Batool, S. A., Chuadhry, M. N. 2009. The impact of municipal solid waste treatment methods on greenhouse gas emissions in Lahore, Pakistan. Waste Management, 29: 63-69.

Berndes, G. 2002. Bioenergy and water-the implications of large-scale bioenergy production for water use and supply. Global Environmental Change, 12: 253-271.

Bhattacharya, S., Salam, P. A. 2002. Low greenhouse gas biomass options for cooking in the developing countries. Biomass and Bioenergy, 22: 305-317.

Bhutto, A. W., Bazmi, A. A., Zahedi, G. 2011. Greener energy: Issues and challenges for Pakistan-Biomass energy prospective. Renewable and Sustainable Energy Reviews, 15: 3207-3219.

Chen, Y., Cheng, J. J., Creamer, K. S. 2008. Inhibition of anaerobic digestion process: a review. Bioresource Technology, 99: 4044-4064.

Dasappa, S., Paul, P., Mukunda, H., Rajan, N., Sridhar, G., Sridhar, H. 2004. Biomass gasification technology-a route to meet energy needs. Current Science, 87: 908-916.

Dinda, S. 2004. Environmental Kuznets curve hypothesis: a survey. Ecological Economics, 49: 431-455.

Fermoso, J., Arias, B., Plaza, M. G., Pevida, C., Rubiera, 
F., Pis, J.J., Garcia Peria, F., Casero, P. 2009. Highpressure co-gasification of coal with biomass and petroleum coke. Fuel Processing Technology, 90: 926-932.

Frost, R. 1973. Some testing experiences and characteristics of boulder-gravel fill in earth dams. A Symposium presented at the $75^{\text {th }}$ Annual Meeting of ASTM International (Evaluation of Relative Density and its Role in Geotechnical Projects Involving Cohesionless Soils) June 25-30, California, USA.

Gunaseelan, V. N. 1997. Anaerobic digestion of biomass for methane production: a review. Biomass and Bioenergy, 13: 83-114.

Hammer, J. M., Ullestad, D. C., Wesoloski, S. J. 1982. Method and apparatus for power load shedding: Google Patents.

Hayat, A. 2007. Irrigation sector development in Punjab (Pakistan): Case study of district Sargodha. $M s$ Thesis, Linkopings University, Sweden, 56 pp.

Jamil, F. 2013. On the electricity shortage, price and electricity theft nexus. Energy Policy, 54: 267-272.

Kessides, I. N. 2013. Chaos in power: Pakistan's electricity crisis. Energy Policy, 55: 271-285.

Khan, A. 2015. Economic Feasibility of Biomass Gasification for Electricity Generation in Pakistan. Global Journal of Science Frontier Research (E), 15: 19-23.

Khan, A., Nawaz, K., Usama, M., Ashraf, Z. 2015. Feasibility Study of Municipal Plastic Waste for Power Generation in Lahore City, Pakistan. Journal of Chemical Engineering \& Process Technology, 6:229.doi: 10.4172/2157-7048.1000.229

Khan, M. A., Abu-Ghararah, Z. H. 1991. New approach for estimating energy content of municipal solid waste. Journal of Environmental Engineering, 117: 376-380.

Kugelman, M. 2013. Pakistan's Energy Crisis. National Bureau of Asian Research, Washington, DC., USA.

Laurikka, H. 2006. Option value of gasification technology within an emissions trading scheme. Energy Policy, 34: 3916-3928.

Lynd, L. R. 1996. Overview and evaluation of fuel ethanol from cellulosic biomass: technology, economics, the environment, and policy. Annual Review of Energy and the Environment, 21: 403-465.

Miao, X., Wu, Q. 2004. High yield bio-oil production from fast pyrolysis by metabolic controlling of Chlorella protothecoides. Journal of Biotechnology, 110: 85-93.
Mirza, U. K., Ahmad, N., Harijan, K., Majeed, T. 2009. Identifying and addressing barriers to renewable energy development in Pakistan. Renewable and Sustainable Energy Reviews, 13: 927-931.

Mirza, U. K., Ahmad, N., Majeed, T. 2008. An overview of biomass energy utilization in Pakistan. Renewable and Sustainable Energy Reviews, 12: 1988-1996.

Mohan, D., Pittman, C. U., Steele, P. H. 2006. Pyrolysis of wood/biomass for bio-oil: A critical review. Energy \& Fuels, 20: 848-889.

Morris, M., Waldheim, L. 1998. Energy recovery from solid waste fuels using advanced gasification technology. Waste Management, 18: 557-564.

Myers, N. 1997. The World's Forests and their Ecosystem Services. In: Nature's Services: Societal Dependence on Natural Ecosystems, G.C. daily (ed).) pp: 215235, Island Press, Washington, DC, USA

Nazir, M. 1991. Biogas plants construction technology for rural areas. Bioresource Technology, 35: 283289.

Newsham, G. R., Bowker, B. G. 2010. The effect of utility time-varying pricing and load control strategies on residential summer peak electricity use: a review. Energy Policy, 38: 3289-3296.

Noman, O. 1988. The Political Economy of Pakistan, $1947-85,1^{\text {st }}$ edition, Taylor \& Francis, USA. ISBN13: 978-0710302113,

Polprasert, C. 2007. Organic Waste Recycling: Technology and Management: $3^{\text {rd }}$ edition, IWA Publishing, London, UK.

Qureshi, A. S. 2005. Climate change and water resources management in Pakistan. In: Climate Change and Water Resources in South Asia, M.M.Q. Mirza and Q.K. Ahmad (eds.), pp.197-230, AA Balkema Publishers, Leiden, Netherlands.

Qureshi, A. S., Shah, T., Akhtar, M. 2003. The GroundWater Economy of Pakistan. Working Paper 64, Pakistan Country Series No.19, International Water Managent Institute, IWMI, Srilanka.

Sahir, M. H., Qureshi, A. H. 2008. Assessment of new and renewable energy resources potential and identification of barriers to their significant utilization in Pakistan. Renewable and Sustainable Energy Reviews, 12: 290-298.

Shafizadeh, F. 1982. Introduction to pyrolysis of biomass. Journal of Analytical and Applied Pyrolysis, 3: 283-305.

Sheikh, M. A. 2010. Energy and renewable energy scenario of Pakistan. Renewable and Sustainable Energy Reviews, 14: 354-363. 
Shekdar, A. V. 2009. Sustainable solid waste management: an integrated approach for Asian countries. Waste Management, 29: 1438-1448.

Siddiqui, R., Jalil, H. H., Nasir, M., Malik, W. S., Khalid, M. 2008. The cost of unserved energy: evidence from selected industrial cities of Pakistan. The Pakistan Development Review, 47: 227-246.

Sthiannopkao, S., Wong, M. H. 2013. Handling e-waste in developed and developing countries: Initiatives, practices, and consequences. Science of the Total Environment, 463: 1147-1153.

Tariq, M.A.U.R., van de Giesen, N. 2012. Floods and flood management in Pakistan. Physics and Chemistry of the Earth, Parts A/B/C, 47: 11-20.

Weiland, P. 2010. Biogas production: current state and perspectives. Applied Microbiology and Biotechnology, 85: 849-860.

Yang, H., Yan, R., Chen, H., Lee, D. H., Zheng, C. 2007. Characteristics of hemicellulose, cellulose and lignin pyrolysis. Fuel, 86: 1781-1788.

Zhang, R., El-Mashad, H. M., Hartman, K., Wang, F., Liu, G., Choate, C., Gamble, P. 2007. Characterization of food waste as feedstock for anaerobic digestion. Bioresource Technology, 98: 929-935. 